\title{
Production Efficiency of Broiler Farming in Thailand: A Stochastic Frontier Approach
}

\author{
Areerat-Todsadee ${ }^{1}$, Hiroshi-Kameyama ${ }^{2}$, Kamol Ngamsomsuk $^{3}$, \& Koh-en Yamauchi ${ }^{2}$ \\ ${ }^{1}$ Faculty of Agriculture, United Graduate School of Agricultural Sciences, Ehime University, Japan \\ ${ }^{2}$ Faculty of Agriculture, Kagawa University, Kagawa, Japan \\ ${ }^{3}$ Faculty of Agriculture, Chiang Mai University, Thailand \\ Correspondence: Areerat-Todsadee, Faculty of Agriculture, United Graduate School of Agricultural Sciences, \\ Ehime University, Japan. E-mail: todsadee@yahoo.co.th
}

Received: August 16, 2012 Accepted: August 28, 2012 Online Published: November 15, 2012

doi:10.5539/jas.v4n12p221 URL: http://dx.doi.org/10.5539/jas.v4n12p221

\begin{abstract}
This paper considers translog stochastic frontier model in which the effects of technical inefficiency are defined by the Battese and Coelli model, which imposed a common temporal pattern upon all broiler farms. In this study, efficiency score of broiler farms in northern Thailand were estimated. The goal of this paper was to analyze variations in the production and technical inefficiencies of Thai broiler farms in the northern region. The results showed that feed, bird stocks, operating costs, and other costs were important factors to broiler output in the Chiang Mai Province. It also showed that the socio-economic situation of farmers appears to have effect technical efficiency at the farm level. The results suggest that, there is opportunity to improve broiler production in the region by adopting appropriate management practices.
\end{abstract}

Keywords: broiler, production, technical inefficiency, stochastic frontier

\section{Introduction}

Poultry production is a heavy concentration in Asia. It is a major proportion of the chick population in the world. Asian chicken meat output represented about $35 \%$ of the global total compared with around $32 \%$ back in 2000 (Terry, 2010).

The poultry sector has been widely acknowledged as the greatest agro-business success story in Thailand. Poultry industry has become a major "industrial" livestock sectors, the rapid growth of the poultry is broiler, and it was produced $86.4 \%$ of the total poultry meat. From an economic perspective, broiler meat is the important poultry product, both for domestic consumption and export. In 2001, 1,230 million tons of poultry meat was produced, making it export country, with 399 million tons exported. In 2003, Thailand is one of the world's largest chicken meat producers (ranked 7 in 2003 with production of 1,340 billion tons).

However, the growth rate fell only in the past few years, mainly because of the impact of HPAI (Note 1); the number of chicken dropped to 180 million in 2004 and increase stock to 254 million birds in 2005 but fell again to 184 million birds in 2006. This situation had forced to broiler farmers to close down and made it difficult for existing or expand firm. Some farmers could not survive financially due to the high cost production input, like feed, medicine and the marketing control by companies. In addition, the development of poultry has been lopsided. Most of the poultry farms are concentrated near the metros where there are well-organized markets. About half of the country's chickens are raised in the central Thailand; second in term of poultry production is the northeastern region, which is physically the largest of Thailand. While the North region is the third poultry activity and the South region is the fourth to produce the broilers.

To better understand the problem of broiler production in Thailand, we examined the production efficiency (Note 2) of resource used by using the stochastic frontier with inefficiency model. The stochastic frontier model is used in a large literature of studies of production, cost, revenue, profit and other model of goal attainment (Battese \& Coeli, 1992; Colli, 1995; Aigner et al., 1997). SFA model makes it possible to not only statistically verify the 
variables used in the model, but also measure probabilistic error and inefficiency. However, the distribution of the inefficiency must be assumed in advance.

In this study, Chiang Mai province is chosen, because the area is characterized by significant variations in temperature range; in term of resource endowment, given that broilers is sensitive to change in temperature, the matter of ensuring maximum productivity would require this condition be inherently favorable to lower the cost of controlling diseases and the environment. The objectives of this paper are; to assess the effects of factors of production on broiler chicks, measure technical efficiency level and determine the major factors that affect technical efficiency, and finally recommend policy measure to improve broiler production.

\section{Study Area and Data}

Cross-section data are used in this study. The survey carried out during the October to November, 2011. A sample of 52 broiler farms, which are located mainly in the Chiang Mai Province, Thailand, was surveyed for this analysis. Figure 1 is a map of Chiang Mai province's Thailand with the round square representing sampled districts.

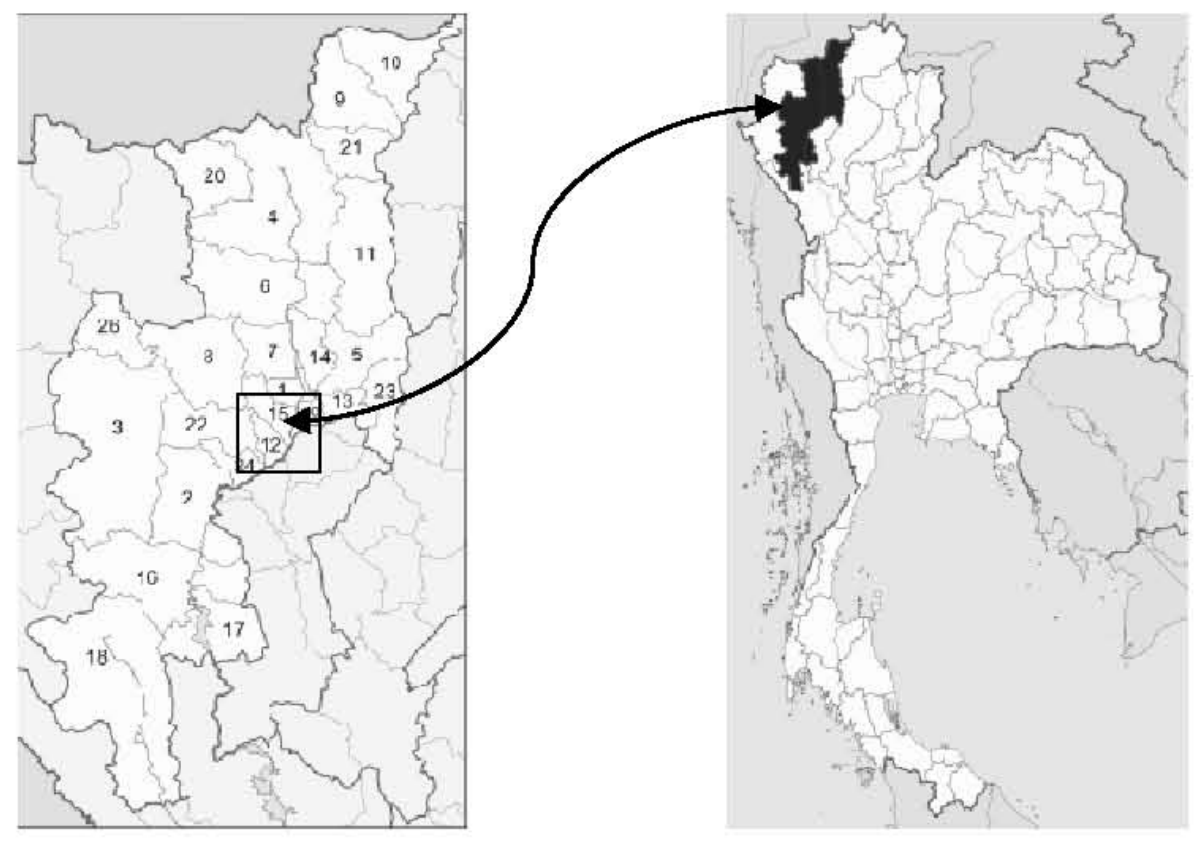

Figure 1. Map of Thailand and the study area

Note: The survey covered 6 districts in Chiang Mai Province (left picture) of Thailand (right picture) such as Chiangmai city, Doi Saket, Mae Rim, San Kamphang, Sansei, Mae Wan as shown in the square box.

These districts were chosen randomly from each of four pre-determined agro-economic zones. The survey includes broiler production information, socio-economic of each broiler farmer. The production data for each farm include bird stock, feed, labor, fixed costs, and variable costs. The socio-economic information includes age, education level, family size, experience of farmers, income, gender, status, loan bank, and etc.

Summary of the variables used in the stochastic frontier production function is presented in Table 1 . The mean value of broiler production was 352,113 birds per farm, while the mean total fixed costs represented THB 31,000 and mean total variables cost represented THB 22,472.9. The mean farm size was 9,086.54 birds with a minimum size of 600 birds.

This result showed that broiler production in this study was the large-scale category. This agreed with the FAO's classification (2003) that the large-scale farms have chicken more than 5,000 birds. Feed consumption was the major component of poultry production in the study area. The feed required to produce the output showed a mean value of $2,736.19 \mathrm{~kg}$. The average labor was 60.48 man-days (2 labors for 30 days). While minimum labor was 20 man-days. 
Table 1. Summary statistics of study variables of broiler sectors farmer

\begin{tabular}{cccccc}
\hline Variable name & Mean & Minimum & Maximum & SD & CV \\
\hline Output & 352,113 & 25,000 & $1,000,000$ & 3958.56 & 88.95 \\
Bird Stock & $9,086.54$ & 600 & 20,000 & 4299.66 & 2.11 \\
Feed & $2,736.19$ & 220 & 6,250 & 1251.89 & 2.19 \\
Labor & 60.48 & 20 & 133.75 & 29.60 & 2.04 \\
Fixed costs & 31,000 & 18,000 & 40,000 & 6680.84 & 4.64 \\
Total variable cost & $22,472.9$ & 4,000 & 50,000 & 1251.89 & 17.96 \\
Age & 53.62 & 40 & 72 & 8.51 & 6.30 \\
Year of schooling & 6.25 & 4 & 12 & 2.67 & 2.34 \\
Family size & 4.13 & 2 & 7 & 1.04 & 3.97 \\
Experience of farmers & 24.67 & 11 & 47 & 9.89 & 2.49 \\
Access to credit & 0.59 & 0 & 1 & 0.50 & 1.18 \\
\hline
\end{tabular}

Note: 1 baht $=0.033$ USD (December, 2011)

Source: Author calculation

Furthermore, commercial poultry farmers in this study were relatively older, with a mean age of approximately 54 years. According to the survey, the average education level of farmers was approximately six years, which means they had completed primary school. The average family size was four persons per farm, while the average' years of production experience were approximately 24.67. Lastly, the survey found that some farmers had taken out loans from banks; borrowing from other lenders to invest in broiler farming was at $59 \%$.

\section{Methodology}

We have consider the stochastic frontier model as it appears in the current literature was originally developed by Ainger, Lovell and Schmidt (1977) and Meeusen and van den Broeck (1977). A production frontier model can be written as:

$$
Y_{i}=f\left(x_{i} ; \beta\right) T E_{i}
$$

where $y_{i}$ is the output of farm $\mathrm{i}(\mathrm{i}=1, \ldots, \mathrm{N}), x_{i}$ is a vector of $\mathrm{N}$ input used by the farm $\mathrm{i}, \mathrm{f}\left(x_{i} ; \beta\right)$ is the production frontier, and $\beta$ are parameter to be estimated. Let be the technical efficiency of farm $i$,

$$
T E_{i}=\frac{y_{i}}{f\left(X_{i} ; \beta\right)}
$$

where TE denotes technical efficiency defined as the ratio of observed output to maximum feasible output. $\mathrm{TE}_{\mathrm{i}}=$ 1 shows the $\mathrm{i}$-th farm obtains the maximum feasible output, while $\mathrm{TE}_{\mathrm{i}}<1$ provides a measure of the shot fall of the observed output from maximum feasible output.

To incorporate the fact that output can be affected by random shocks into the analysis, a stochastic component that describes random shock affecting the production process is added. The stochastic production frontier will become:

$$
y_{i}=f\left(x_{i} ; \beta\right) \cdot T E_{i} \cdot \exp \left(v_{i}\right)
$$

where $f\left(x_{i} ; \beta\right) \exp \left(v_{i}\right)$ is the stochastic frontier, which consists of deterministic part $f\left(x_{i} ; \beta\right)$ common to all farmers and a farmer-specific part $\exp \left(\mathrm{v}_{\mathrm{i}}\right)$ which captures the effect of the random shock to each farers. If we specify that the production frontier is stochastic, the model purposed as:

$$
T E_{i}=\frac{y_{i}}{f\left(X_{i} ; \beta\right)^{\prime} \exp \left(v_{i}\right)}
$$

We assume that $T E_{i}$ is also s stochastic variable, with a specific distribution function, common to all farms. 
If we combine Equations (1) and (3), assuming a Cobb-Douglas specification, the stochastic frontier production function for this study could be written as follow:

$$
\text { In } y_{i}=\beta_{0}+\sum_{i=1}^{m} \beta_{j} \quad \text { In } x_{i j}+v_{i}-u_{i} ; i=1,2, \ldots, N
$$

where $y_{i}$ is the output of farms, $\mathbf{x}_{\mathrm{ij}}$ is the amount of input $\mathrm{j}$ used by farm $\mathrm{i}, \beta_{\mathrm{j}}$ are parameter to be estimated. The output values are bounded above by the stochastic variable, $\exp \left(\mathrm{X}_{\mathrm{ij}}+\mathrm{v}_{\mathrm{i}}\right)$. The random error, $\mathrm{v}_{\mathrm{i}}$ can be positive or negative an so the stochastic frontier.

Equation (5) specifies the stochastic frontier production function in terms of original production values. However, the technical inefficiency effects, $\mathrm{u}_{\mathrm{i}}$ 's are assumed to be a function of explanatory variables. Following Battese and Coelli (1995), $U_{i}$ 's can be expected as :

$$
U_{i}=Z_{i} \delta+W_{i}
$$

where $Z_{i}$ is a $1 \times p$ vector of variables that may influence efficiency of a farm; $\delta$ is an $p \times 1$ vector of parameters to be estimated; and $\mathrm{W}_{\mathrm{i}}$ 's are random variables defined by the truncation of the normal distribution with mean 0 and variance, $\sigma_{u}^{2}$, such that the point of truncation is $-Z_{i} \delta$, i.e. $W_{i} \geq-Z_{i} \delta$. These assumptions are consistent with $\mathrm{U}_{\mathrm{i}}$ being a non-negative truncation of the $\mathrm{N}\left(\mathrm{Z}_{\mathrm{i}} \delta, \sigma_{u}^{2}\right)$ distribution (Battese \& Coelli, 1995).

The technical efficiency of production for the i-th farm $\left(T E_{i}\right)$ is defined as:

$$
T E_{i}=\exp \left(-U_{i}\right)=\frac{Y}{f\left(X_{i} ; \beta\right) \exp \left(V_{i}\right)}
$$

\subsection{Specification Model}

First, a translog (TL) stochastic frontier model employed to do in this paper. It is tested for decide about functional specification that best suits the data on the Chiang Mai's broiler farming as shown in the Equation 5 .

$$
\ln Y_{i}=\beta_{0}+\beta_{I} \operatorname{In} x_{s}+\beta_{2} \operatorname{In} x_{f}+\beta_{3} \operatorname{In} x_{c}+\beta_{4} \operatorname{In} x_{v}+v_{i}-u_{i}
$$

For farm specific technical inefficiency, Battese and Coelli (1995) model will be obtained:

$$
u_{i}=\exp (-u)=b_{0}+b_{1} A G E+b_{2} E D U+b_{3} F F+b_{4} E X P+b_{5} A C+e
$$

However, technical inefficiency could be estimated if the technical inefficiency effects, $u_{i}$ were stochastic and have particular distributional properties (Coelli \& Battese, 1996). The null hypothesis was used to test the technical efficiency effect $(\gamma=0)$ and influence of specification farm to inefficiencies $\left(\delta_{\mathrm{A}}=\ldots=\delta_{\mathrm{T}} 0 ; \gamma=0\right)$. Hence, stochastic frontier model could reduce the traditional average function in which the explanatory variables in the technical inefficiency model are included in the production function.

For testing the hypothesis as well as other released hypotheses, the generalized likelihood-ratio statistic is used, $\lambda$, given by:

$$
\lambda=-2\left[\ln \left\{L\left(H_{0}\right)\right\}-\ln \left\{L\left(H_{1}\right)\right\}\right]
$$

where $L\left(H_{0}\right)$ and $L\left(H_{l}\right)$ denoted the values of likelihood function under the null $\left(H_{0}\right)$ and alternative $\left(H_{1}\right)$ hypotheses, respectively. If the null hypothesis is true, $\lambda$ has approximately $\chi^{2}$-distribution when the null hypothesis involves $\gamma=0$.

In order to estimate farm specific production and technical inefficiency model two sets of variables are need. A description to the variables is given in the following sections. In the production function, output $\left(\mathrm{Y}_{\mathrm{i}}\right)$ is value of chicken, measured in Baht, and input are: (1) number of broiler $\left(\mathrm{X}_{\mathrm{s}}\right)$; (2) total labor $\left(\mathrm{X}_{1}\right)$, including hired and family labor, measured in man-day; (3) purchased feed $\left(\mathrm{X}_{\mathrm{f}}\right)$, measure in $\mathrm{Kg}$.; (4) fixed costs $\left(\mathrm{X}_{\mathrm{c}}\right)$ is Capital cost includes depreciation, farm building, farm machineries, and other farm equipment, measured in Baht; and (5) total variable costs $\left(\mathrm{X}_{\mathrm{v}}\right)$ including electricity, water, gas, tax costs, measured in Baht. These variables agree with Kalirajan and Shand (1994) that farmer efficiency depends on the technological know-how and on the socio-economic conditions under which they work. Following these lines, we have selected age's farmers (AGE), measured in years; education attainment, measured in how many years that each farmers study in school; Family size, measured in household number; experience of farmers, measured in how many years that farmers growth chick; access to credit, measured in dummy variable- 1 if the farmer obtained credit for production activities and 0 otherwise (see Table 2). 
Table2. Variable descriptions for analysis of production and technical inefficiency of broiler farming

\begin{tabular}{ccl}
\hline Variables & Unit & \multicolumn{1}{c}{ Description } \\
\hline & & \multicolumn{1}{c}{ Frontier production function } \\
\cline { 3 - 3 } $\mathrm{Y}_{\mathrm{i}}$ & Baht & Value of bird stock \\
$\mathrm{X}_{\mathrm{s}}$ & Number & Quantity of bird stock \\
$\mathrm{X}_{\mathrm{l}}$ & Man-days & Hired and family labor used in production \\
$\mathrm{X}_{\mathrm{f}}$ & Kg. & Amount of broiler feed used \\
$\mathrm{X}_{\mathrm{c}}$ & Baht & Capital cost incurred in the production which includes depreciation and interest on farm \\
& & building and construction, farm machineries, and other farm equipment \\
$\mathrm{X}_{\mathrm{v}}$ & Baht & Total variable costs such as electricity, water, gas, tax costs. \\
& & \\
\cline { 3 - 3 } AGE & Years & Age's farmers \\
EDU & Years & Number of years of education \\
FF & Number & Number of household \\
EXP & Years & Number of years of experience in broiler farming \\
AC & Dummy & Access to credit \\
\hline
\end{tabular}

Source: field survey.

\section{Result and Discussion}

\subsection{Estimation of Ordinary Least Square}

Ordinary least-square (OLS) was estimation for operating of the broiler farmers. The parameters are showed in Table 3. The inputs used in the model were able to explain $99 \%$ (adjusted $\mathrm{R}^{2}=0.99$ ) of the variation in broiler production for the study area. The co-efficient of bird stock, feed, fixed cost, and total variables cost are significant and have expected signs-Labor was negative and insignificant in the broiler production which implies that it does not have effect on the output. Since the parameter estimates of variable labor were individually insignificant in the model, a statistical test can be performing whether to decide to include this variable in the model.

In order to test the linear restriction on the parameter of this variable, $t$ statistic could be used to test this joint linear restriction. Labor is accepted the null hypothesis ( $p$-value $=0.74$ ), which implying the acceptance of the null hypothesis of joint insignificance. Therefore, the analyses in the following subsequent section will be based on all variables, including, birds stocks, feed, fixed costs, and total variables cost.

Table 3. Ordinary lest square estimation

\begin{tabular}{cccc}
\hline Variables & Parameter & Coefficients & Std. Error \\
\hline Constant & $\beta_{0}$ & $4.39^{* *}$ & 0.48 \\
Bird Stock $\left(\mathrm{X}_{\mathrm{s}}\right)$ & $\beta_{1}$ & $0.60^{* *}$ & 0.21 \\
Feed $\left(\mathrm{X}_{\mathrm{f}}\right)$ & $\beta_{2}$ & $0.82^{* *}$ & 0.21 \\
Labor $\left(\mathrm{X}_{\mathrm{l}}\right)$ & $\beta_{3}$ & -0.09 & 0.74 \\
Fixed cost $\left(\mathrm{X}_{\mathrm{c}}\right)$ & $\beta_{4}$ & $0.16^{* * *}$ & 0.15 \\
Total variables cost $\left(\mathrm{X}_{\mathrm{v}}\right)$ & $\beta_{5}$ & $-0.49^{*}$ & 0.08 \\
\hline
\end{tabular}

Note: $\mathrm{R} 2=0.99, \mathrm{~N}=52 ; * * *$ Significant at $1 \%$ level, and $* *$ significant at $5 \%$ level and * significant at $10 \%$ level; F-test $=0.000$.

Source: Author calculation

\subsection{Maximum Likelihood Estimation of Stochastic Frontier Production Analysis}

The result of broiler production was obtained by using the maximum likelihood estimation. It is represented in Table 4. There were instances of technical inefficiency effects in broiler production. The sigma square of 0.99 is highly statistically significant. This result indicated a good fit and the correctness of the specified distribution 
assumption of the composite error term was $99 \%$. The estimate of the lambda parameter associated with the variance in the stochastic frontier model was $24 \%$. This means that the systematic effects unaccounted for by the production frontier function are the dominant source of the stochastic random error. In other words, an approximately $24 \%$ variation in the output level of broilers raised could be attributed to the relevance of the stochastic parametric production function and maximum likelihood estimation.

From the results, feed appeared to be the most important production factor, with the elasticity of 0.67 and was significant at the $10 \%$ level. This is in agreement with the concept of weight gain in broiler production and the physiology of feed conversion in poultry production. Broilers that are well fed gain weight faster, attain marketable weights earlier, and are sold at higher unit prices. This result conformed to the earlier studies conducted by E. J. Udoh and N. A. Etim (2009) and P. C. Ike (2011). The birds stock appeared to be the second most important production factor, with an elasticity of 0.63 , and was significant at $5 \%$ and $10 \%$ levels, and implies that every one percent increase in stock size, would lead 0.62 percent increase in the value of broiler produced. This is in agrees with Effiong (2005), Nwachuku and Onyenweaku (2007), and Ezeh et al (2012) that larger the stock size could less inefficient production of broiler.

Total variable costs appeared to be the third most important production factor, with an elasticity of 0.46 . This result confirmed the importance of water, proper lighting and labor in broiler production, but the sign was negative. However, fixed costs were found to be significant in the production process, with an elasticity of 0.16 . This showed that the required for production affects broiler output.

The estimated co-efficiency of the inefficiency function provided some explanation for the relative technical efficiency level among the individual farms. All characteristic variables, the co-efficient of the other inefficiency variables were insignificant at $1 \%, 5 \%, 10 \%$ levels.

The estimated co-efficient for age of the farmers was negative which indicates that other farmers were more technically efficient in broiler production than younger ones. On the other hand, negative correlation existed between the year of formal education and technical inefficiency, implying that any increase in the value of this variable results in a rise in production efficiency. This also shows that farmers level of technical inefficiency declines with more formal education (Oluwaatusin et al, 2011). Education was negative effect on technical inefficiency, implying that any increase in the value of this variable results in a rise in production. This also showed that farmers level of technical inefficiency declines with more formal education.

Table 4: Maximum-likelihood estimation of the SFPF and inefficiency function for broiler farmers in Thailand

\begin{tabular}{llll}
\hline Variables & Parameter & Co-efficiency & t-rations \\
\hline Production frontier & & & \\
Constant & $\beta_{0}$ & 4.69 & $0.310^{* * *}$ \\
Bird stock $\left(\mathrm{X}_{\mathrm{s}}\right)$ & $\beta_{1}$ & 0.63 & $0.190^{* *}$ \\
Feed $\left(\mathrm{X}_{\mathrm{f}}\right)$ & $\beta_{2}$ & 0.67 & $0.196^{*}$ \\
Fixed costs $\left(\mathrm{X}_{\mathrm{c}}\right)$ & $\beta_{3}$ & 0.16 & $0.077^{* *}$ \\
Total variables cost $\left(\mathrm{X}_{\mathrm{v}}\right)$ & $\beta_{4}$ & -0.46 & $0.145^{* * *}$ \\
Inefficiency & & & \\
Constant & $\delta_{0}$ & 0.262 & 4.277 \\
AGE & $\delta_{1}$ & -0.008 & 0.0473 \\
EDU & $\delta_{2}$ & -0.166 & $0.787^{*}$ \\
FF & $\delta_{3}$ & 0.56 & 0.719 \\
EXP & $\delta_{4}$ & 0.005 & 0.0624 \\
AC & $\delta_{5}$ & -0.388 & 0.8735 \\
\hline Sigma square & & 0.99 & \\
Lambda & & $0.23^{*}$ & \\
Log likelihood function & & 14.95 & \\
\hline
\end{tabular}

Note: Figure in parenthesis represent standard errors; ***Significant at 1 per cent level, and $* *$ significant at 5 percent level and * significant at 10 percent level.

Source: Author calculation. 
The estimated co-efficient for family size was positively related to technical inefficiency. This implied that as the number of household member increase, technical inefficiency increase and this leads to reduction in technical efficiency. This was in conformity with the finding of Muhammad et al (2009). In addition, experience of farmer had a negative influence on technical inefficiency. This indicated that farmer with more experience tended to be more technically efficient (Alrwis \& Francis, 2003; Ike \& Inoni, 2006; Ike, 2008). Finally, access to credit had a negative effect on technical inefficiency. This show that financial was more technical efficiency in broiler production.

\subsection{Technical Efficiency Analysis}

The predicted farms specific technical efficiency (T.E.) for each category of farmer is presented in Table 5. Technical efficiency ranged between 0.11 and 1.00 , with an overall mean of 0.79 . This suggests that on average, the farms in all categories operated $11 \%$ below their respective mean efficiency levels.

Table 5. Frequency distribution of technical efficiency of broiler farms in Thailand

Source: Author calculation

\begin{tabular}{lcc}
\hline Efficiency Score & No. of farm & Percentage \\
\hline$<0.50$ & 6 & 11.54 \\
$0.51-0.59$ & 1 & 1.92 \\
$0.60-0.69$ & 10 & 19.23 \\
$0.70-0.79$ & 23 & 44.23 \\
$0.80-0.89$ & 7 & 13.46 \\
$0.90-1.00$ & 5 & 9.61 \\
\hline Mean & \multicolumn{3}{c}{0.79} & \\
Maximum & \multicolumn{2}{c}{1.00} \\
Minimum & \multicolumn{2}{c}{0.11} \\
Total Farmers & 52 \\
\hline
\end{tabular}

Furthermore, it was observed that $44.23 \%$ of the broiler producers the largest proportion of the farmers have technical efficiency levels between $0.70 \%$ and $0.79 \%$. This result agreed with Ojo (2003) that majority of the farmers have technical efficiency between 0.70 and 0.79 , while, $1.92 \%$ of farmers have levels between $0.51 \%$ and $0.59 \%$. However, the second largest group of farmers- $19.23 \%$-has technical efficiency scores between $0.60 \%$ and $0.69 \%$.

The next largest group accounts for $13.46 \%$ of the farmers, with a technical efficiency between $0.80 \%$ and $0.89 \%$. Furthermore, $11.54 \%$ of famers have technical efficiency scores of less than $50 \%$., while, only $9.61 \%$ realize more than $0.90 \%$. Farmers' failure to maximize production output may be due to their lack of appropriate management practices.

\subsection{Hypotheses Tests for $\gamma$ and $\delta$-parameters}

As indicated in the methodology, the results of various hypotheses for broiler production model are presented in Table 6. First null hypothesis was regarding the existence of inefficiency factor $\left(\mathrm{H}_{0}: \delta_{0}=\delta_{\mathrm{A}}=\ldots=\delta_{\mathrm{C}}=0\right)$. Here, the null hypothesis was rejected at the $5 \%$ level which implies that the model existences of inefficiency.

Table 6. Hypothetical test for model specification and statistical assumptions

\begin{tabular}{lccc}
\hline \multicolumn{1}{c}{ Item and $\mathrm{H}_{0}$} & Likelihood-ratio test & $\chi^{2}$ & Decision \\
\hline $\begin{array}{l}\text { 1.No inefficiency effect } \\
\left(\mathrm{H}_{0}: \delta_{0}=\delta_{\mathrm{A}}=\ldots=\delta_{\mathrm{C}}=0\right)\end{array}$ & 18.713 & 11.911 & Reject $\mathrm{H}_{0}$ \\
$\begin{array}{l}\text { 2.No effects of inefficiency factors included in the inefficiency model } \\
\left(\mathrm{H}_{0}: \delta_{\mathrm{A}}=\ldots=\delta_{\mathrm{C}}=0\right)\end{array}$ & 18.648 & 10.371 & Reject H0 \\
3.No age effect $\left(\mathrm{H}_{0}: \delta_{\mathrm{A}}=0\right)$ & 12.66 & 2.706 & Reject H0 \\
4.No education effect $\left(\mathrm{H}_{0}: \delta_{\mathrm{E}}=0\right)$ & 16.968 & 2.706 & Reject $\mathrm{H} 0$ \\
5.No family size effect $\left(\mathrm{H}_{0}: \delta_{\mathrm{F}}=0\right)$ & 12.935 & 2.706 & Reject $\mathrm{H} 0$ \\
6.No farmers experience effect $\left(\mathrm{H}_{0}: \delta_{\mathrm{EX}}=0\right)$ & 12.571 & 2.706 & Reject $\mathrm{H} 0$ \\
7.No credit effect $\left(\mathrm{H}_{0}: \delta_{\mathrm{C}}=0\right)$ & 12.568 & 2.706 & Reject $\mathrm{H} 0$ \\
\hline
\end{tabular}

Note: Critical value for hypotheses are obtained by Kodde and Palm (1986, p.1246); all values are significant at $5 \%$ level of significance.

Source: Author calculation. 
The next null hypothesis was testing for the factors effect on the inefficiency model $(\mathrm{H} 0: \delta \mathrm{A}=\ldots=\delta \mathrm{C}=0)$. As the result, the hypothesis was rejected at $5 \%$ level which indicates that the model involved inefficiency factors in the technical inefficiency effects. The other hypotheses, three to seven, were testing for individual effect on the technical inefficiency. All hypotheses were rejected at $5 \%$ statistical significance level which implies that individual effect on the technical inefficiency.

\section{Conclusion}

In this study, SFA was estimated under the specification of translog function with inefficiency effects. The operational aspect of maximum likelihood simulation model was applied to obtain parameter estimates of this model. This study suggested a useful extension of the stochastic frontier model. The cross data were collected from the sampling of 52 broiler farms in the Chiang Mai Province-the survey covered the north, south, east, and west zones.

The results show that feed, bird stock, fixed cost, and total variable costs were important factors contributing to broiler output in Chiang Mai Province. Another interesting result found is that the total variable costs of production had a negative sign, which means that electricity, water, tax, etc., indirect affect the output. However, age, education, family size, training and access to credit, were found to be technical inefficiencies of farmers' abilities to produce output in this province. This implies that socio-economic assistance to farmers positively affects on the technical efficiency at the farm level.

According to technical efficiency of this study, the results show relatively substantial technical inefficiency on broiler farms in the Chiang Mai Province of Thailand. The mean technical efficiency is estimated $79 \%$. Moreover, the farmers' technical efficiency score range from $44.23 \%$ of broiler producers the largest proportion of the farmers having technical efficiency between $0.70 \%$ and $0.80 \%$ to $9.61 \%$ of farmers having a technical efficiency score of more than $0.90 \%$. The results suggest that, there is opportunity to improve broiler production in the region by adopting appropriate management practices. The heterogeneity in management and production practices employed by farmers with varying socio-economic situation may explain the distribution of technical efficiency.

\section{Acknowledgements}

The authors thank Provincial Livestock Office in Chiang Mai province of Thailand is also gratefully acknowledged for providing the data on Chiang Mai province and Dr. Narin Throngvitaya. Moreover, the authors would like to thank all broiler farmers who contributed to this survey.

\section{References}

Achilles, C. (2004). A review of the Thailand poultry sector. Livestock information, Sector Analysis and Policy Branch (SAGAL). Food and agriculture organization of the United Nations. Retrieved from http://www.fao.org/ag/againfo/resources/en/publications/sector_reports/lsr_THA.pdf

Aigner, D. J., Lovell, C. A. K., \& Schmidt, P. (1997). Formulation and estimation of stochastic frontier production function models. Econometrics, 6, 21-37. Retrieved from http://www.rand.org/pubs/papers/2008/P5649.pdf

Ajibefun, I. A., Battese, G. E., \& Kada, R. (1996). Technical efficiency and technological change in the Japanese rice industry: A stochastic frontier analysis (CEPA). Working Paper 96/09, Department of Economics, University of New England (Armidale: Australia).

Alris, K. N., \& Francis, E. (2003). Technical efficiency of broiler farms in the Central Region of Saudi Arabia: Stochastic frontier approach (pp. 5-34). Agricultural research center, King Saudi Arabia University.

Animal Feed Business (2006). Poultry Meat Market and Export. Animal feed business magazine, 21(99), 44-55.

anonymous. (2010). Poultry and product annual. Thailand poultry and products semiannual overview February 2005. Retrieved from http://www.themeatsite.com/

Bagi, F. S., \& Hunag, C. I. (1983). Estimating production technical efficiency for individual farm in Tenese. Canadian agricultural economics, 31, 249-56. http://dx.doi.org/10.1111/j.1744-7976.1983

Battes, G. E., \& Corra, G. S. (1997). Estimation of a production frontier model with application to the Pastoral zone of Eastern Australia. Australian agricultural economics, 21, 169-179. http://dx.doi.org/10.1111/j.1467-8489.1977.tb00204.x

Battese, G., \& Coelli, T. J. (1992). Frontier Production Function, technical efficiency and panel data: With application to Paddy farmers in India. Productivity analysis, 3, 153-199. http://dx.doi.org/10.1007/BF00158774 
Battese, G., \& Coelli, T. J. (1995). Frontier production function and technical efficiency: A survey empirical aplications in agricultural economics. Agricultural economics, 7, 185-208. http://dx.doi.org/10.1016/0169-5150(92)90049-5

Binuomote, S. O., Ajetomobi, J. O., \& Ajao, A. O. ( 2008). Technical efficiency of poultry egg producers in Oyo state of Nigeria. Poultry science, 7(12), 1227-1231. http://dx.doi.org/10.3923/ijps.2008.1227.1231

Choprakan, K., Wattanalkul, V., Wongvisit, K., \& Suriyachanthrathong, V. (2000). Indigenous chicken and hybrid chicken: past and present (p. 80). Faculty of Agriculture, Ubon Ratchathani University. Thailand. Research Foundation, Ratchatewi, Bangkok. (In Thai).

Coelli, T. J. (1994). A guide to FRONTIER version 4.1: A computer program for Stochastic Frontier Production and Cost Function Estimation. Department of econometrics, university of New England (Armidale). Retrieved from http://www.uq.edu.au/economics/cepa/frontier.php

Coelli, T. J., Prasada Rao, D. S., \& Battese, G. E. (1998). An introduction to efficiency and productivity analysis. London:UK: Kluwer academic publishers. http://dx.doi.org/10.1007/978-1-4615-5493-6

Colli, T. J. (1995). Recent development in frontier modeling and efficiency measurement. Australian Agriculture Economics, 39(3), 215-245.

Colli, T. J., \& Battese, G. E. (1996). Identification of factors which influence the technical inefficiency of Indian farmers. Australian agricultural economics, Australian agricultural and resource economics society, 40(2), 103-108. http://dx.doi.org/10.1111/j.1467-8489.1996.tb00558.x

Department of Livestock Development (DLD) (2003). Annual report, Department of livestock development, Ministry of agriculture and agricultural cooperative. Bangkok, Thailand.

Depdas, B., \& Arabinda, D. (2006). On measure of technical inefficiency and production uncertainly in stochastic frontier production model with correlated error component. Business Media, 26, 165-180. http://dx.doi.org/10.1007/s11123-006-0011-9

Effiong, E. O. (2005). Efficiency of production in selected livestock enterprises in Akwa-lbom state, Nigeria. PHD. Thesis, Dept. of agricultural economic, Michael Okpara University of agricultural, Umudike.

Etim, N. A., \& Udoh, E. J. (2006). Efficiency of resource utilization: The case of broiler production by urban in Uyo Metropolis. Proceedings of the $40^{\text {th }}$ Annual Conference of the Agricultural Society of Nigeria (ANS). Held at National Root Crops Research Institute, Umudike, Abia State, 16-20 $0^{\text {th }}$ October, 2006.

Ezeh, C. I., Anyiro, C. O., \& Chukwu, J. A. (2012). Technical efficiency in poultry broiler production in Umuahia capital territory of Abia state, Nigeria. Greener agricultural science, 2(1), 001-007.

FAO. ( 2003). The livestock industries of Thailand. RAP publication no 2002/23. Animal production and health commission for Asia and the Pacific agriculture organization of United Nations. Retrieved from http://www.fao.org/WAIRDOCS/LEAD/X6170E/x6170e00.htm

Farrell, M. J. (1975). The measurement of productive efficiency. Royal statistical society, 120, 253-290. Retrieved from http://www.jstor.org/stable/2343100

Ferrier, G., \& Lovell, C. (1990). Measuring cost efficiency in banking: Econometric and linear programming evident, Econometric, 46, 229-245. $\quad$ Retrieved from http://econpapers.repec.org/article/eeeeconom/v_3a46_3ay_3a1990_3ai_3a1-2_3ap_3a229-245.htm

Forsund, F., Lovell, C., \& Schmidt, P. (1980). A survey of frontier production functions and their to relationship to efficiency measurement. Econometric, 13, 5-25. http://dx.doi.org/10.1016/0304-4076(80)90040-8

Fried, H., Lovell, C., \& Schmidt, S. (1993). The measurement of productive efficiency: Technical and applications. New York: Oxford University Press.

Gary, M., \& Sakchai, P. (2009). Thailand poultry and products annual. Global agricultural information network (GAIN). GAIN Report Number: TH9131.

Griffiths, W. E., Hill, R. C., \& Judge, G. G. (1993). Learning and practicing econometric. John Willey and Sons. INC.

Hallam, D., \& Machado, F. (1996). Efficiency analysis with panel data: a study of Portuguese dairy farms. European review of agricultural economics, 12, 79-93. Retrieved from http://www.erae.oupjournals.org/ More information through EDIRC.

Ike, P. C. (2008). Estimating production technical efficiency of lrvingia seed (ogbono) species farmers in Nsukka 
Ike, P. C. (2011). Resource use and technical efficiency of small scale poultry farmers in Enugu state, Nigeria: A agricultural zone of Enugu State, Nigeria. Sustainable agricultural resource, 28, 1-7.

Ike, P. C., \& Inoni, O. E. (2006). Determinants of yam production and economic efficiency among small holder farmers in Southeastern Nigeria. Central European agriculture, 7, 337-342. http://dx.doi.org/10.1093/erae/23.1.79

Kalirajan, K. P., \& Shand, R. T. (1994). Economics in disequilibrium, an approach from the frontier. Delhi: Macmillan India.

Kalirajan, K. P., \& Shand, R. T. (1997). Source of output growth in Indian agriculture. Indian agricultural economics, 52(4), 3-17.

Kodde, D. A., \& Palm, F. C. (1986). Wald criteria for jointly testing equality and inequality restriction. Econometric, 54(5), 1243-1248. http://dx.doi.org/10.2307/1912331

Kumbhakar, S. C., \& Lovell, C. A. K. (2000). Stochastic frontier analysis (Cambridge, UK). http://dx.doi.org/10.1017/CBO9781139174411

Md. Ferdous, A., Md. Akhtaruzzaman, K., \& Anwarul, H, A. S. M. (2011). Technical efficiency in tilapia farming of Bangladesh: a stochastic frontier production approach. Aquaculture International, 1-16.

Meeusen, W., \& Van Den, B. (1997). Efficiency estimation from Cobb-Douglas production function with composed error. International Economic Review, 18, 435-444. http://dx.doi.org/10.2307/2525757

Muhammad-Lawal, A., Omotesho, O. A., \& Falola, A. (2009). Technical efficiency of youth participation in Agriculture: A case study of the youth-in-agricultural program in ONDO state, South Westeren Nigeria. Nigerian journal of agricultural, food and environment, 5(1), 20-26.

Nwachuku, I. N., \& Onyenweaku, C. E. (2007). Economic efficiency of Fadama Telfairia production in Lmo State, Nigeria: A translog profit function approach. Agricultural research, 2(4), 87-93.

Ojo, S. O. (2003). Productivity and technical efficiency of poultry egg production in Nigeria. International poultry science, 2(6), 459-464. http://dx.doi.org/10.3923/ijps.2003.459.464

Oluwaatusin, F. M., \& Akeem, A. (2011). A review of literature on agricultural productivity production, social capital and food security in Nigeria (pp. 1-53). Nigeria Strategy Support Program (NSSP) working paper no. 21.

Rachel, S. (2009). The political economy of avian influenza in Thailand. Working Paper 18, Brighton, Los Angeles, USA. Retrieved from http://steps-centre.org/wpsite/wp-content/uploads/Thailand.pdf

Rajendran, K., \& Samarendu, M. ( 2005). Efficiency of milk production in India: a stochastic frontier production function approach. Indian economic and business, 4(2).

Sharma, K., Leung, P., \& Zaleski, H. (1997) Productive efficiency of the swine industry in Hawaii: stochastic frontier vs. data envelopment analysis. Productivity analysis, 8, 447-459.

Stevenson, R. E (1980). Likelihood functions for generalized stochastic frontier estimation. Econometrics, 13(1), 31-64.

Stochastic Frontier Analysis. Poultry science, 10(11), 895-898. http://dx.doi.org/10.3923/ijps.2011.895.898

Terry, E. (2010). Global poultry trends-Asian chicken meat production trends 2010. Market and economics featured articles. Retrieved from http://www.thepoultrysite.com/articles/1749/global-poultry-trends-asian-chicken-meat-production-trends-2 010

Tisdell, C., Murphy, T., \& Kehren, T. (2004). Characteristic of Thailand's commercial pig and poultry industries, with international comparisons. Agriculture and consumer Protection, FAO.

Tsitsika, E., Maravelias, C., Wattage, P., \& Haralabous, J. (2008). Fishing capacity and capacity utilization of pure seiners using data envelopment analysis. Fish science, 74, 730-735. http://dx.doi.org/10.1111/j.1444-2906.2008.01583.x

Udoh, E. J., \& Etim, N. A. (2009). Measurement of farm level efficiency of broiler production in Uyo, Aka Ibom State, Nigeria. World agricultural Sciences, 5(S), 832-836. 
Notes:

Note 1. HAPI: High Pathogenic Avian Influenza (HPAI), has hit Thailand periodically since January 2004. Domestic demand also decreased immediately. The shock affected poultry producers of all sizes. Economically, large producers sustained the biggest losses. The Thai broiler Exporter Association estimates that the industry lost 5-6 million Baht as a result of the outbreaks in 2004 alone (Rachel, 2009).

Note 2. Production efficiency is a measure of the ability of producer to maximize their output using a given set of inputs and technologies and it is an important index for assessing and estimating the productivity or profitability of a producer (Fried et al., 1993). 